
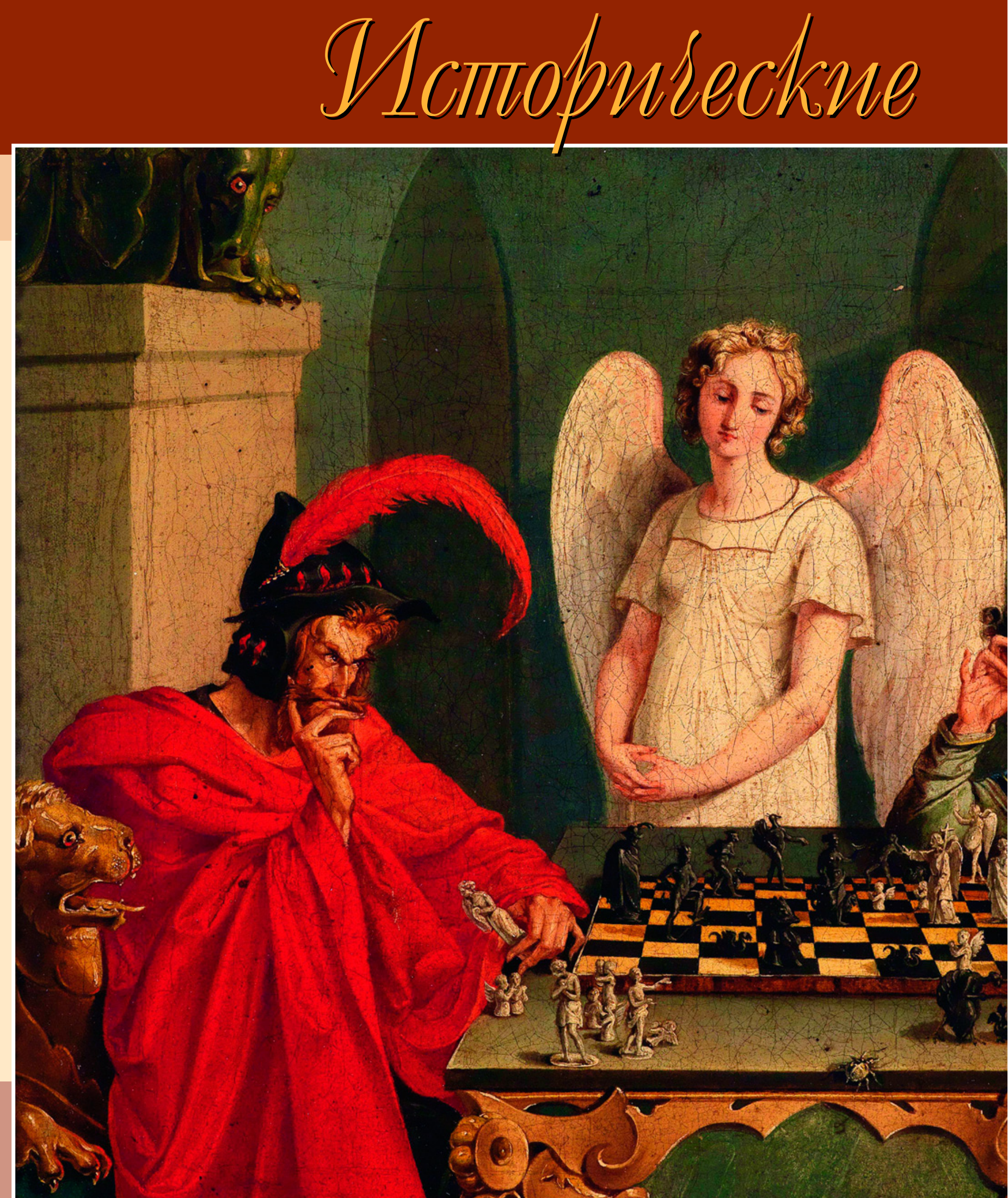

its 5 an

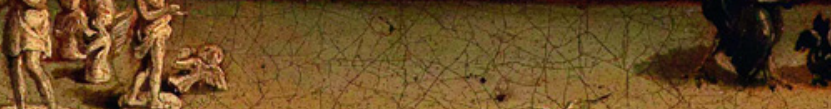
(2) 10.25
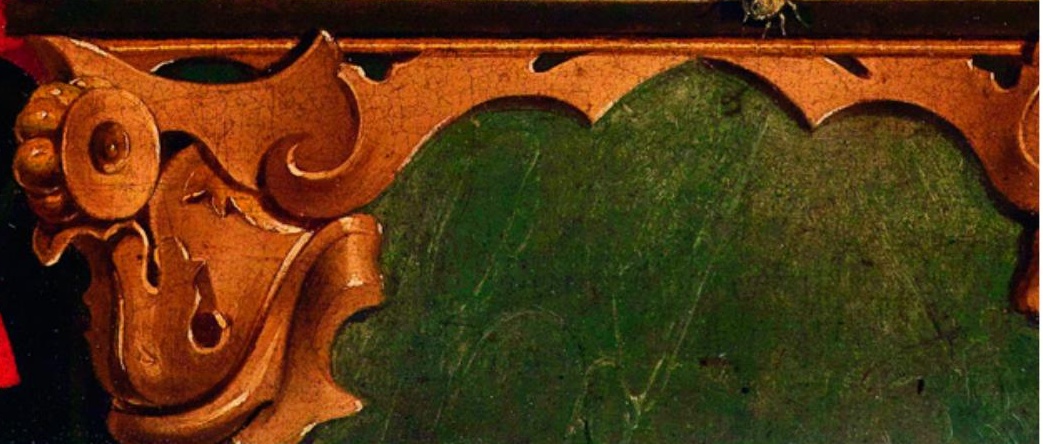

Фауст и Мефистофель играют в шахматы. Неизвестный художник XIX в. Галерея аукционного дома Dorotheum, Вена, Австрия. 


\section{Шахматные байки}

\section{Евгений Гик}

\section{МАТЧ-РЕВАНШ С БОГОМ}

рхиепископ Кентерберийский, живший в XI веке, однажды совершал грогулку по лесу и неожиданно увидел бородатого человека, погруженного в глубокое размышление «Какой-то нищий», - подумал вла-

дька, нө, приблизившись к незнакомцу, заметил у него на коленях шахматную доску.

- О, ваше преосвященство, сказал бородач, - простите, что не могу опуститься на колени и поцеловать вашу руку. Я только что закончил партию и должен выказать своему партнеру величайшую почтительность

- Кто же твой партнер? Я никого не вижу, - удивился архиепископ.

- Господь Бог! Не осуждайте меня, но должен признаться, что иногда я играю с Богом на деньги. В этой партии ставка была 30 гиней, и я проиграл! Прошу ваше преосвященство быть настолько любезным и принять у меня эти 30 гиней. Когда я проигрываю, Господь Бог посылает мне кого-нибудь, кто получает выигрыш.
Архиепископ, известный к тому же жадностью, согласился исполнить Божью волю, взял деньги и уехал в своей карете. Но о странном шахматисте не забыл, и на обратном пути решил снова подойти к нему: вдруг тому опять придется выполнить поручение Всевышнего? Остановив карету, он велел вознице проехать чуть вперед, а сам подошел к шахматисту.

- Как ваши дела, мой друг? На какую сумму вы играете теперь?

- O, сейчас ставка уже пятьсот тридцать гиней. И, видите, на сей раз, моя позиция очень хороша, кажется, Бог получает мат в три хода Смотрите: шах, шах и мат! Я выиграл! И справедливый Господь послал мне вас, ваше преосвященство, чтобы вы за него уплатили.

Такой поворот событий в планы владыки не входил.

- Вы шутите, добрый человек!

- Отнюдь! И это могут подтвердить мои друзья, - решительно заявил шахматист и показал на таких же бородатых людей, как и он, появившихся из-за деревьев.

У архиепископа не осталось другого выхода, кроме какдостать кошелек..

Архиепископ, известный к тому же жадностью, согласился исполнить Божью волю, взял деньги и уехал в своей карете. Но о странном шахматисте не забыл, и на обратном пути решил снова подойти к нему: вдруг тому опять придется выполнить поручение Всевышнего? 


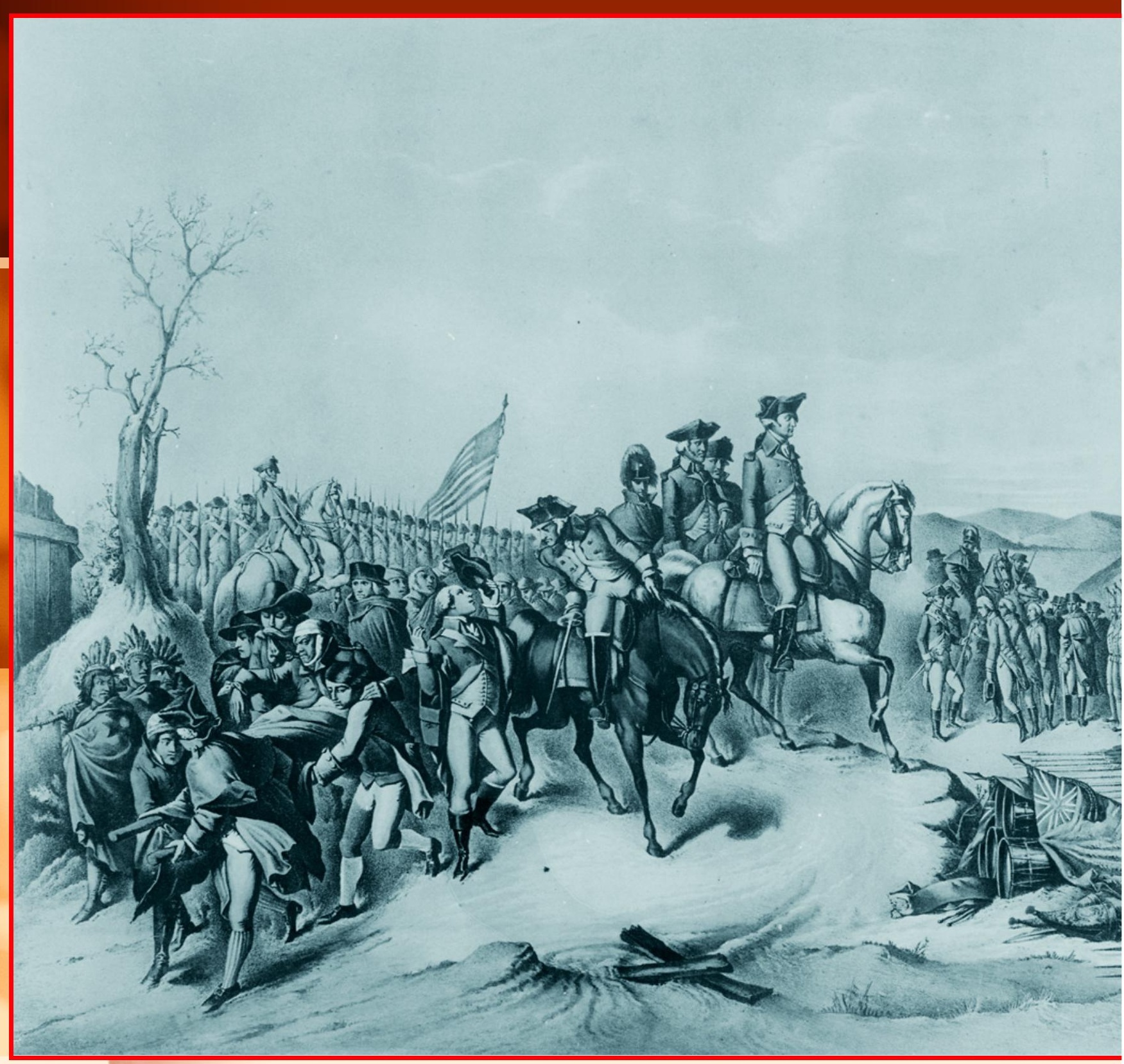

\section{ПРОЩАЙ, АМЕРИКА!}

По мнению британского историка Бенкрофта, в конце XVIII века шахматы сыграли едва ли не решающую роль в войне североамериканских колоний Англии за свою независимость. В канун решающей битвы при Трентоне английский главнокомандующий генерал Рол азартно сражался за шахматной доской как раз в тот момент, когда ему передали сообщение, что силы повстанцев во главе с Джорджем Вашингтоном форсировали реку Делавер. Ролу, увлеченному игрой, было не до того, и он рассеянно сунул срочное донесение в карман. В результате повстанцы получили фору во времени, и это предопределило исход битвы. «Если бы не этот прискорбный случай, - утверждает Бенкрофт, - сама историческая идея возникновения Соединенных Штатов, воз- можно, бесследно исчезла бы, подобно мерцающим огонькам затухающего пламени...»

\section{НЕСОСТОЯВШАЯСЯ ДУЭЛЬ}

Вот что писал американский шахматный журнал сто лет назад: «С сожалением вынуждены сообщить, что второй призер чемпионата Северной Америки Томас Гранди уличен в том, что уговорил двух участников турнира за денежное вознаграждение уступить ему победу в неудачно складывающихся для него партиях. Узнав об этом, победитель состязания капитан Маккензи бросил ему вызов. Отказавшись от дуэли, господин Гранди окончательно уронил свое достоинство в глазах местной общественности и навсегда закрыл себе путь к участию в турнирах Шахматной ассоциации США». 
Капитуляция гессенского отряда Иоганна Ролла у Трентона в декабре 1776 г. Копия литографии, 1850 г.

Внизу:

Игра в шахматы. Худ. Людвиг Дойч. 1896 г.

\section{НАЦИОНАЛЬНАЯ ОДЕЖДА}

Султан и Хан - каждое из двух этих имен, само по себе, означает в применении к Востоку «властелин». Однако обладатель их был невысоким, тихим, безграмотным крестьянином из Пенджаба, которому суждено было стать самым известным «туземцем» в истории шахмат. Когда Султан Хан в начале прошлого века приехал в Англию, его беспрестанно донимали приступы малярии, которую он привез с собой из Индии. Гроссмейстер так часто появлялся на турнирах перебинтованным, что у многих сложилось впечатление, будто это национальная одежда жителей Пенджаба.

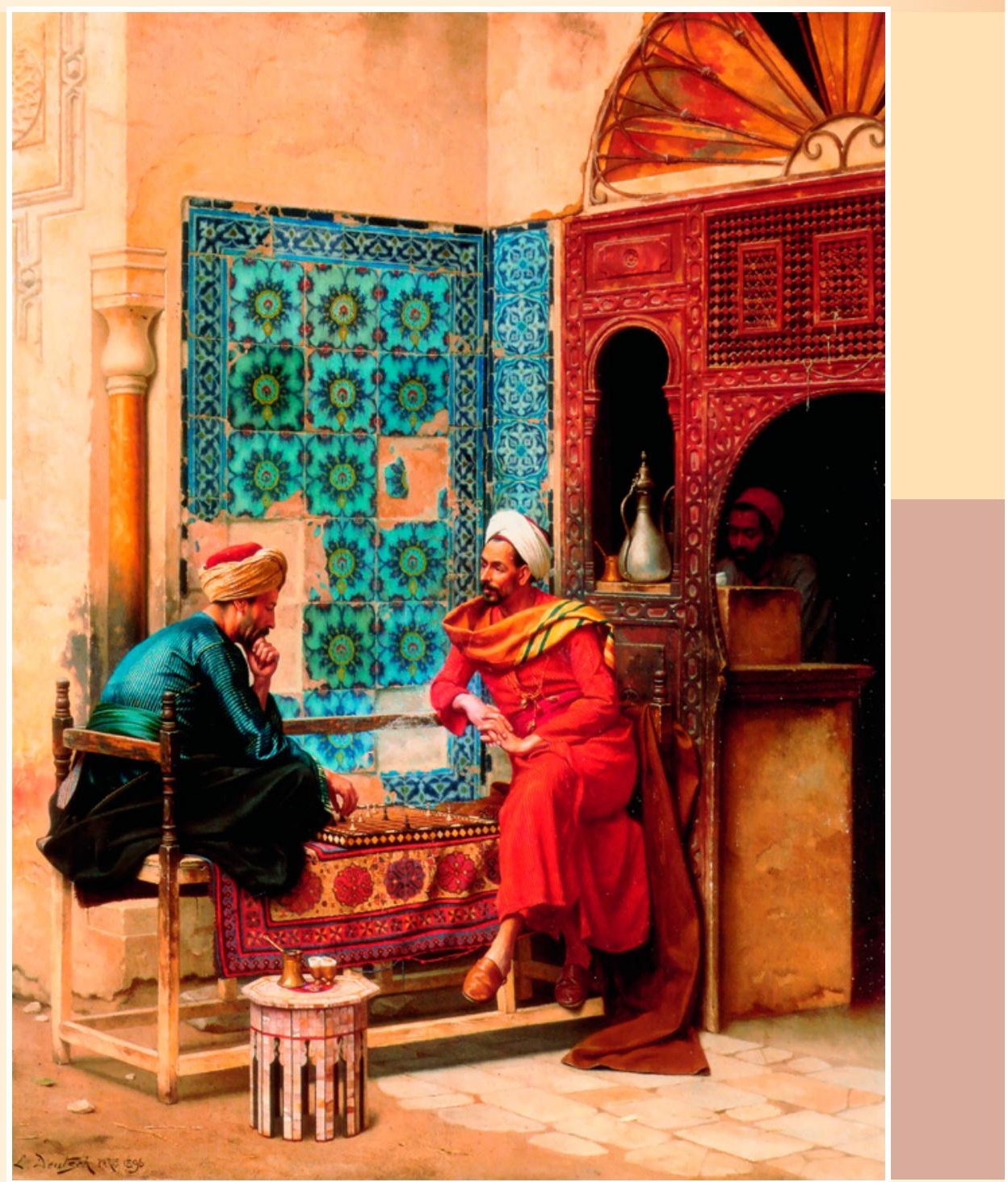




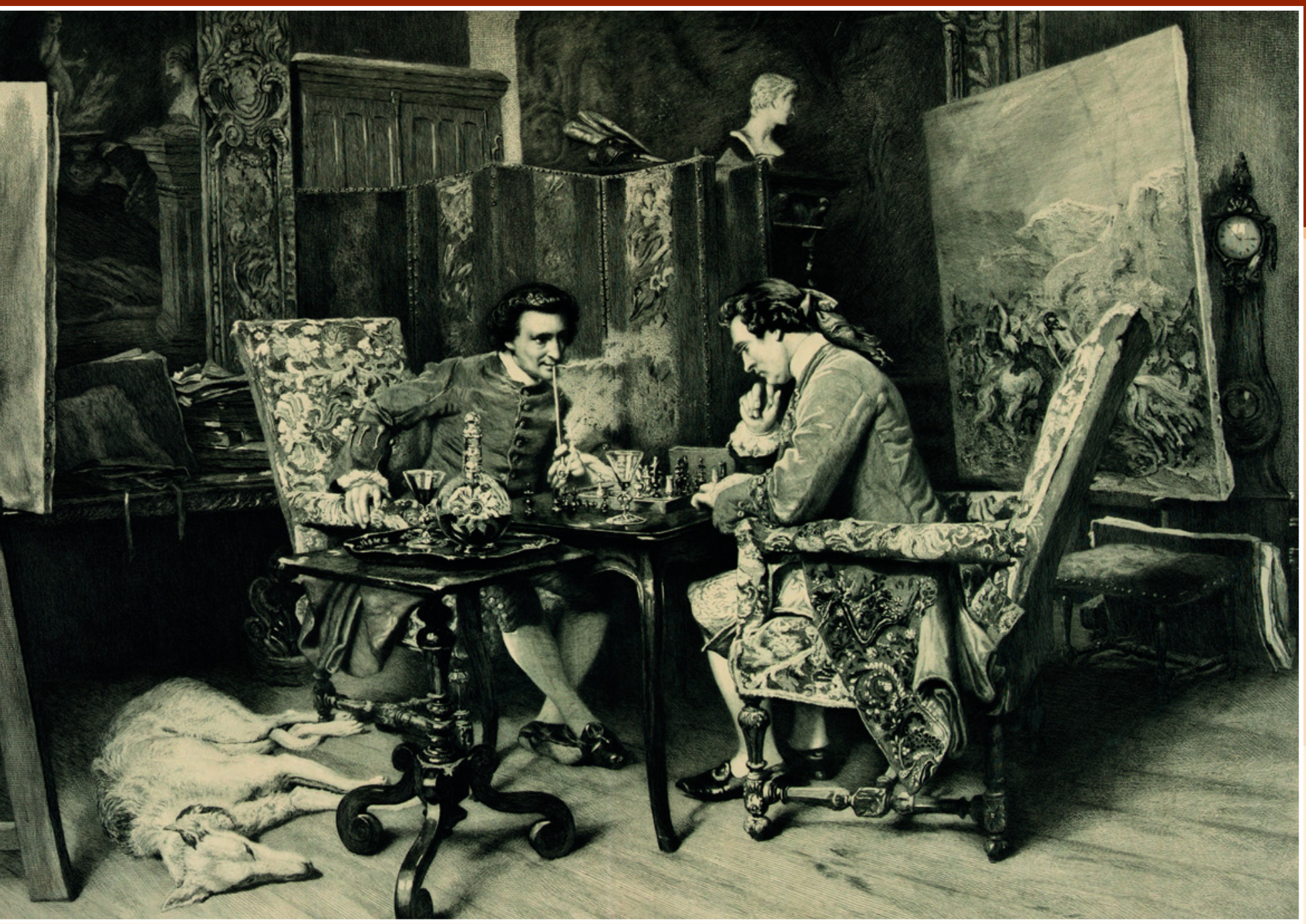

Игра в шахматы. Офорт Жюля Жаке по картине Жана-Луи-Месонье. Около 1858 г. Галерея Сент-Джеймсского дворца, Лондон, Великобритания.

\section{ПРАВИЛА НАДО ЗНАТЬ!}

Людовик VI весьма ловко использовал шахматное правило, согласно которому король - фигура неприкосновенная. Во время Бренвильской битвы французские войска потерпели поражение от англичан. Сам Людовик был окружен неприятельскими солдатами, и один из них, схватив королевского коня за узду, воскликнул:

- Король взят!

Людовик не растерялся и крикнул в ответ

- Вам следовало бы знать правила, доблестный солдат, - короля брать запрещено!

Произошла заминка, удивленные солдаты расступились, и французс- кий монарх, пришпорив коня, спасся от неизбежного плена.

\section{КАЗНИТЬ \\ НЕЛЬЗЯ \\ ПОМИЛОВАТЬ}

Однажды в Зимний дворец привели заключенного. Император Павел I спросил его:

- В шахматы играешь?

- Немного, - скромно ответил арестант.

- Расставляй фигуры, - велел Павел.

Говорят, царь играл неплохо, но все-таки потерпел три поражения кряду.

- Кутайсов! - подозвал император одного из своих фаворитов. - Прикажи отпустить узника на свободу.
Такой замечательный шахматист не может быть преступником!

\section{ОТВЕТ СКЕПТИКУ}

В 1860 году профессор восточных языков из Шотландии Дункан Форбс выпустил книгу «История шахмат», и вскоре стал получать письма от читателей, среди которых было и письмо некоего скептика следующего содержания: «Сэр, в ваших заметках по истории шахмат вы утверждаете, будто известие о восстании мятежных баронов 1216 года застало короля Иоанна Безземельного за партией в шахматы. Меня вы сможете убедить в правдивости этого факта лишь в том случае, если предоставите текст сыгранной королем партии».

На что Форбс немедленно ответил: «Сэр, я вынужден вас разочаровать. Король, о котором идет речь, был неграмотен и при всем желании не мог записать партию...». 


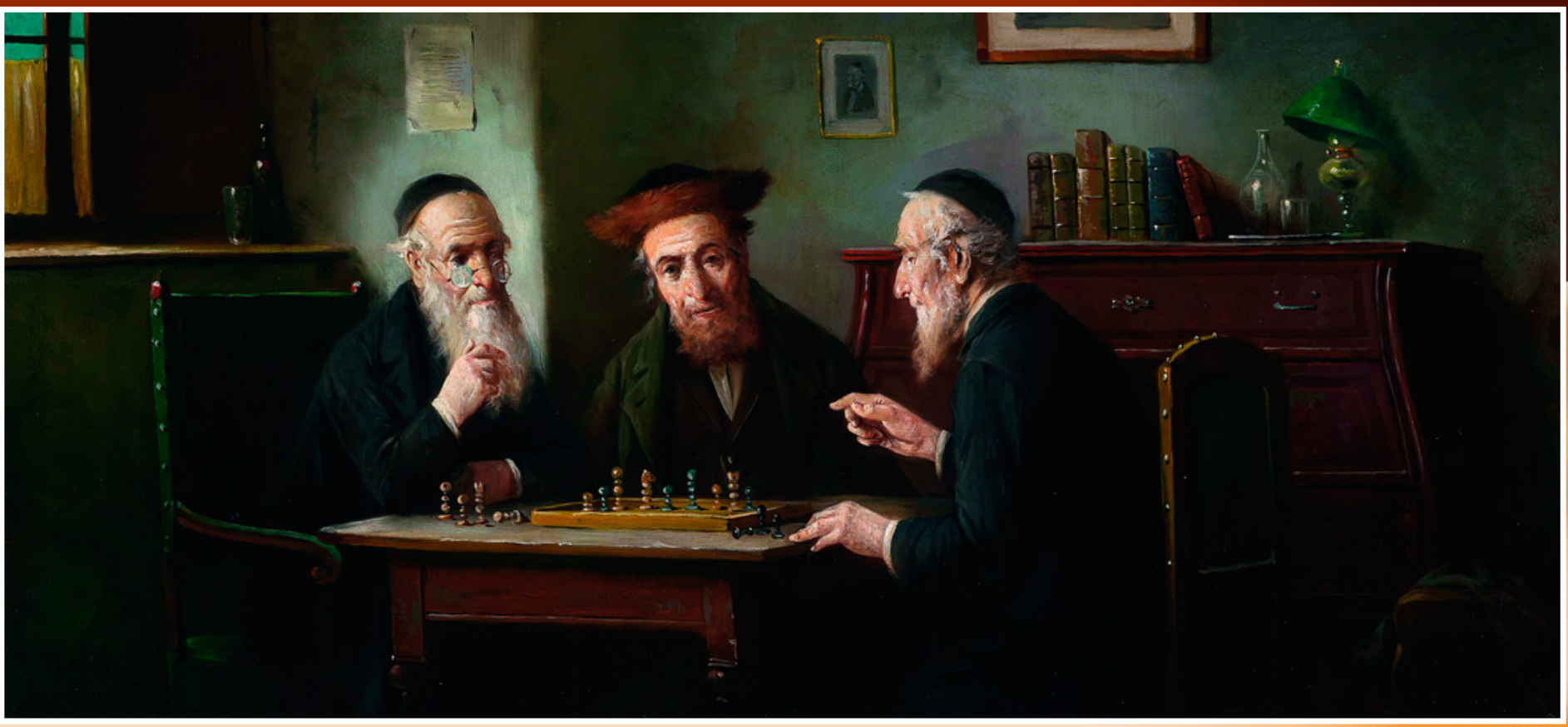

Евреи, играющие в шахматы. Худ. Лайош Колошвари. 1937 г. Галерея аукционного дома Dorotheum, Вена, Австрия.

\section{СМЕРТНЫЙ ГРЕХ}

Один верующий еврей-шахматист обратился к своему раввину с просьбой разъяснить, не совершает ли он тяжкий грех, играя по субботам. Прежде чем дать ответ, священнослужитель предложил ему сыграть несколько партий.

- Играть так, как играете вы, сын мой, - сделал вывод раввин, - смертный грех не только по субботам, но и во все остальные дни недели.

\section{ФилОсоФ}

Спиноза часто играл в шахматы со своим домохозяином. Однажды тот спросил философа:

- Объясните, почему я так волнуюсь, когда проигрываю, в то время как вы после проигрыша совершенно спокойны? Неужели вы так безучастны к игре?

- Отнюдь нет, - ответил Спиноза. Просто когда кто-то из нас проигрывает, один из королей обязательно получает мат, а это всегда радует мое республиканское сердце.

\section{ТРУДНАЯ ПОЗИЦИЯ}

В начале прошлого века в знаменитом лондонском кафе «Гамбит» произошел крайне неприятный случай: прямо во время партии умер один из игроков. Все любители были опечалены, но подошел кто-то из завсегдатаев кафе и успокоил их:

- Не волнуйтесь, господа. Все равно у него была проигранная позиция!

\section{- Отнюдь нет, - ответил Спиноза. - Просто когда кто-то из нас проигрывает, один из королей обя- зательно получает мат, а это всегда радует мое республиканское сердце.}




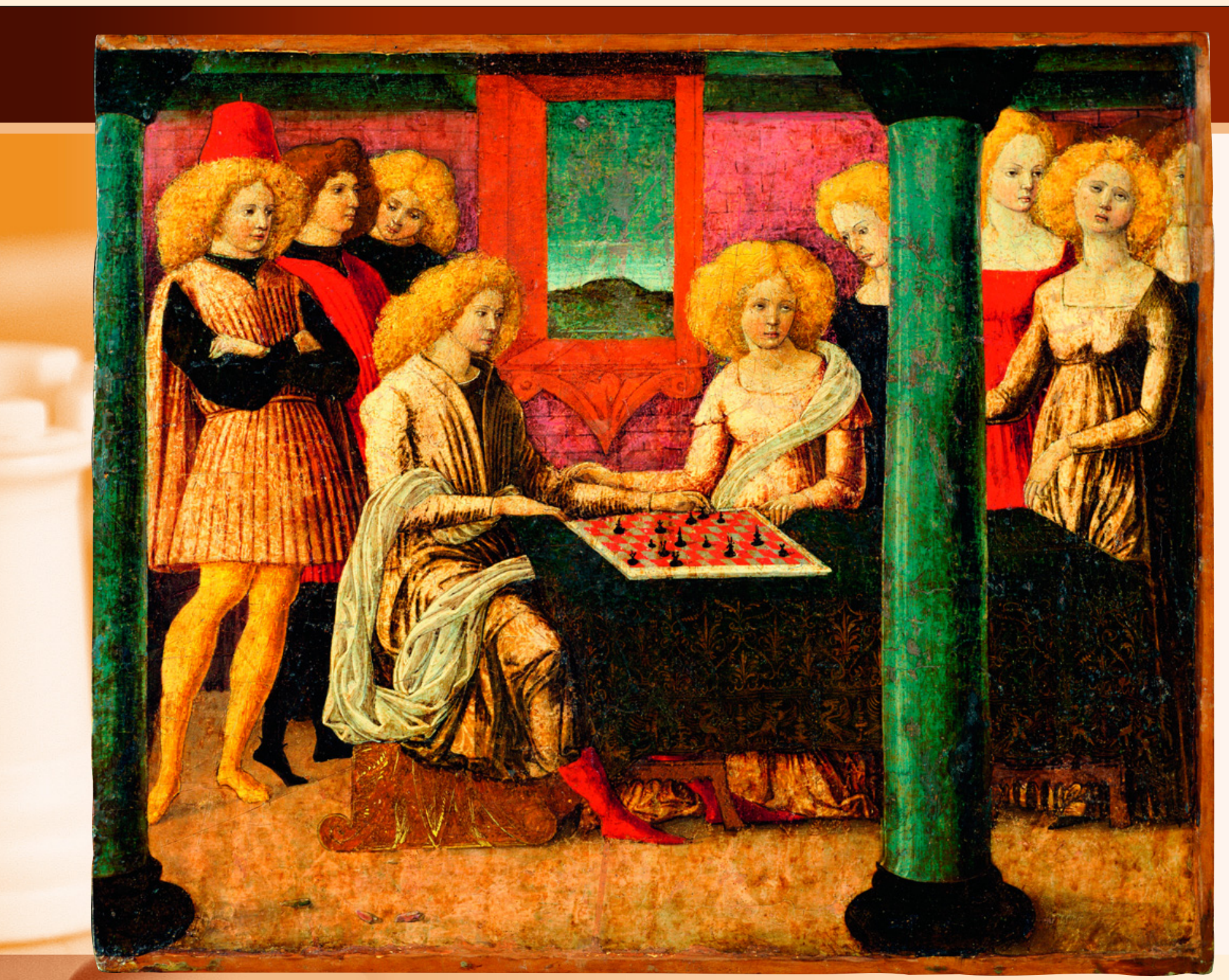

Шахматистки. Худ. Либерале да Верона.Около 1475 г.

Музей Метрополитен, Нью-Йорк, США.

\section{ДАР НЕБЕС}

В памятнике французской куртуазной литературы XIII века «Ключ любви» шахматы рассматривалась как дар небес, ниспосланный влюбленным, поскольку игра давала благоприятную возможность встречаться и мило беседовать без постороннего присутствия. Дуэньи и камеристки, постоянно сопровождавшие девушек, при правильно выбранной стратегии быстро засыпали, предоставляя молодым значительную свободу действий.

\section{УСПЕШНЫЙ КОНКУРС}

На протяжении шестидесяти лет Чарльз Дегруф из американского города Уэйкфилда безуспешно добивался руки своей избранницы Луизы Кирстайн. И, наконец, сердце неприступной мисс Кирстайн дрогнуло. А причиной этого стала победа ее поклонника в шахматном конкурсе, проводимом местной газетой. Чарльзу, кстати, исполнилось всего 95 лет, а Луизе - 93. Вот как важно уметь решать шахматные задачи и этюды! 


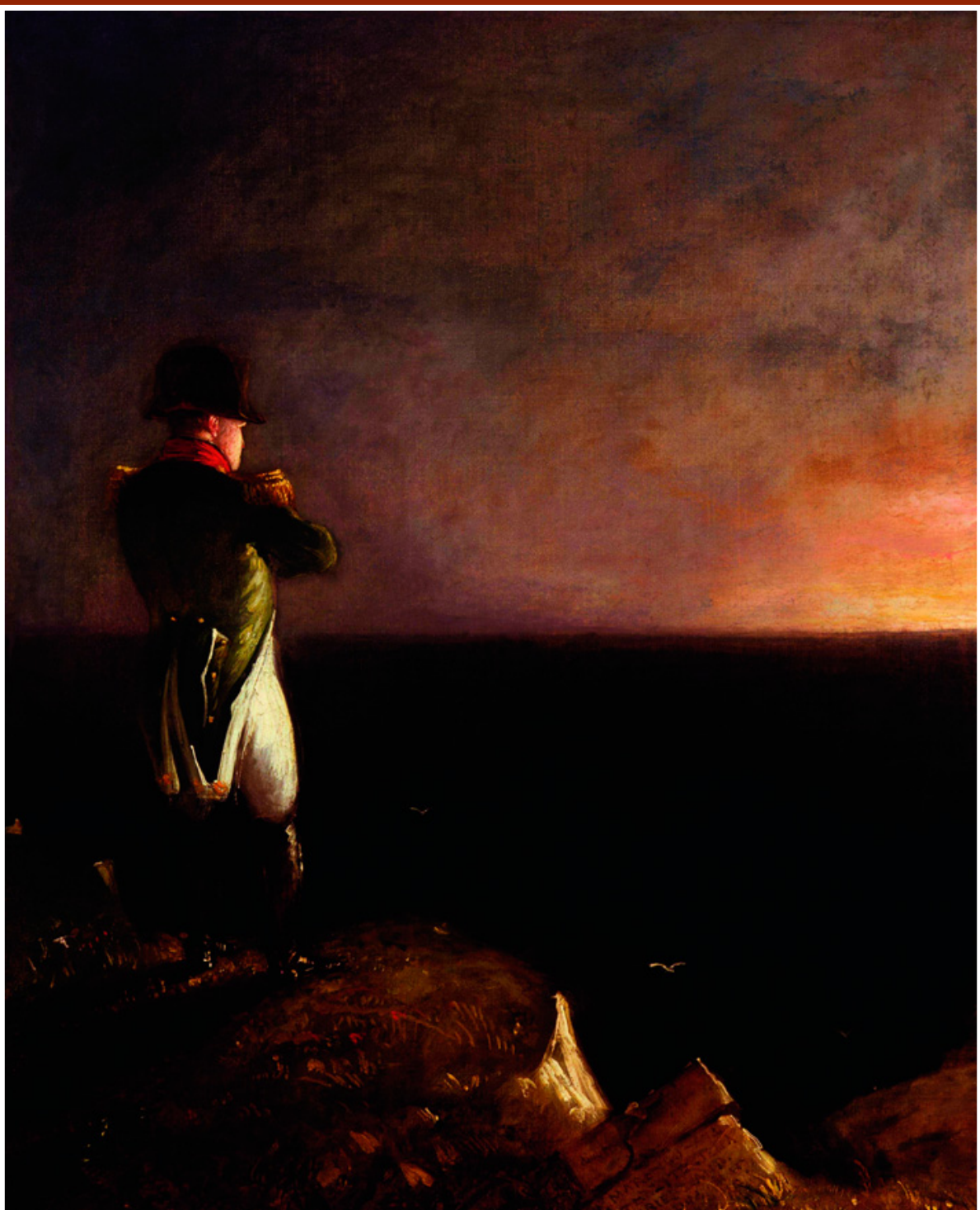

\section{СУДЬБА НАПОЛЕОНА}

Попав на остров Святой Елены, Наполеон мечтал вырваться из плена. Его друзья тщательно продумали план бегства, а инструкцию спрятали в донышко одной из фигур шахматного комплекта, который удалось передать Наполеону. Достаточно было аккуратно отклеить кожаную подкладку под черной ладьей, и великий полководец был бы спасен. Тогда, возможно, история Европы потекла бы совсем по другому руслу. Но, провозившись целый час сначала с королем, а затем с ферзем, Наполеон махнул рукой. Ничего не найдя в этих двух фигурах, он уже не стал браться за ладью - смирился со своей судьбой...
Наполеон на острове Святой Елены. Худ. Орас Верне. $1816-1820$ гг.

риджа встретились однофамильцы двух знаменитых англичан: писательфантаст Герберт Уэллс - Джеймс Уайт. Победил писатель-фантаст, который после партии выразил удивление своему партнеру:

- Кажется, вы сегодня чересчур много фантазировали за доской.

- Зато ваши фигуры действовали как хорошо отлаженная паровая машина, - похвалил его «изобретатель паровой машины».

\section{СУФЛЕРЫ В ПАРТЕРЕ}

Когда в Англии появился первый гроссмейстер, в стране начался настоящий шахматный бум. Это побудило театральных продюсеров все чаще вводить в постановки пьес сцены, в которых действующие лица, рассевшись за доской, разыгрывают какие-нибудь сложные позиции. Однако новинка оказалась довольно опасной. Были отмечены случаи, когда зрители первых рядов партера подсказывали актерам ходы, насмехались над ними и даже бросали в их адрес неприличные слова.

\section{НЕПОБЕДИМЫЙ}

В начале XX века Манхэттенский шахматный клуб посещал один завсегдатай, некий Малькольм Малли, который всем проигрывал. Сильнейшие игроки решили подшутить над ним и в очередном турнире сдались ему во всех партиях. Новый чемпион не понял, что его разыграли, и сильно возомнил о себе. А когда шутники еще дважды повторили этот веселый эксперимент, Малли заявил о своем намерении бороться за шахматную корону. Он отправил вызов одновременно Алехину, Капабланке и Ласкеру. Увы, ни от одного из королей ответ не пришел. И ввиду отсутствия достойных соперников непобедимый Малли полностью отошел от шахмат. Больше в клубе его никто не видел. 


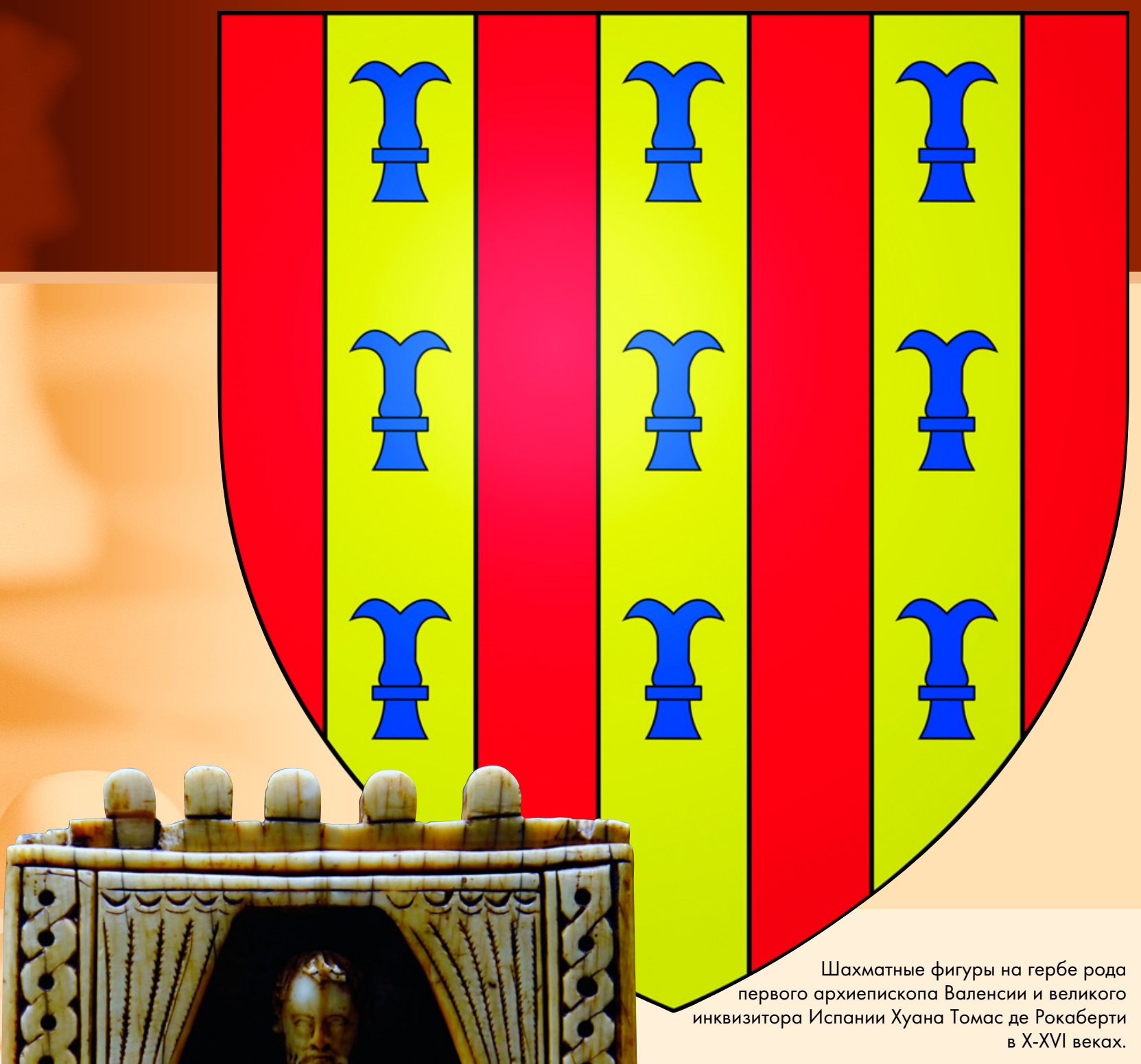

\section{К ВОПРОСУ о ШЛЯПАХ}

В середине XIX века в парижском кафе «Режанс» по воскресеньям иногда было такое скопление публики, что администрация обращалась к посетителям с просьбой не снимать головные уборы, чтобы они не пропали.

\section{ВИННЫЕ ПАРЫ}

В прошлом веке в Стокгольме вышел шахматный учебник некоего фон Кенигстедта, в котором самой ценной рекомендацией была следующая: «За игру принимайтесь до полудня, ибо после обеда винные пары мешают сосредоточиться и вникнуть в тонкости позиции».

Шахматная фигурка короля. XII в. Найдена в южной Италии.

Кабинет медалей, Париж, Франция. 


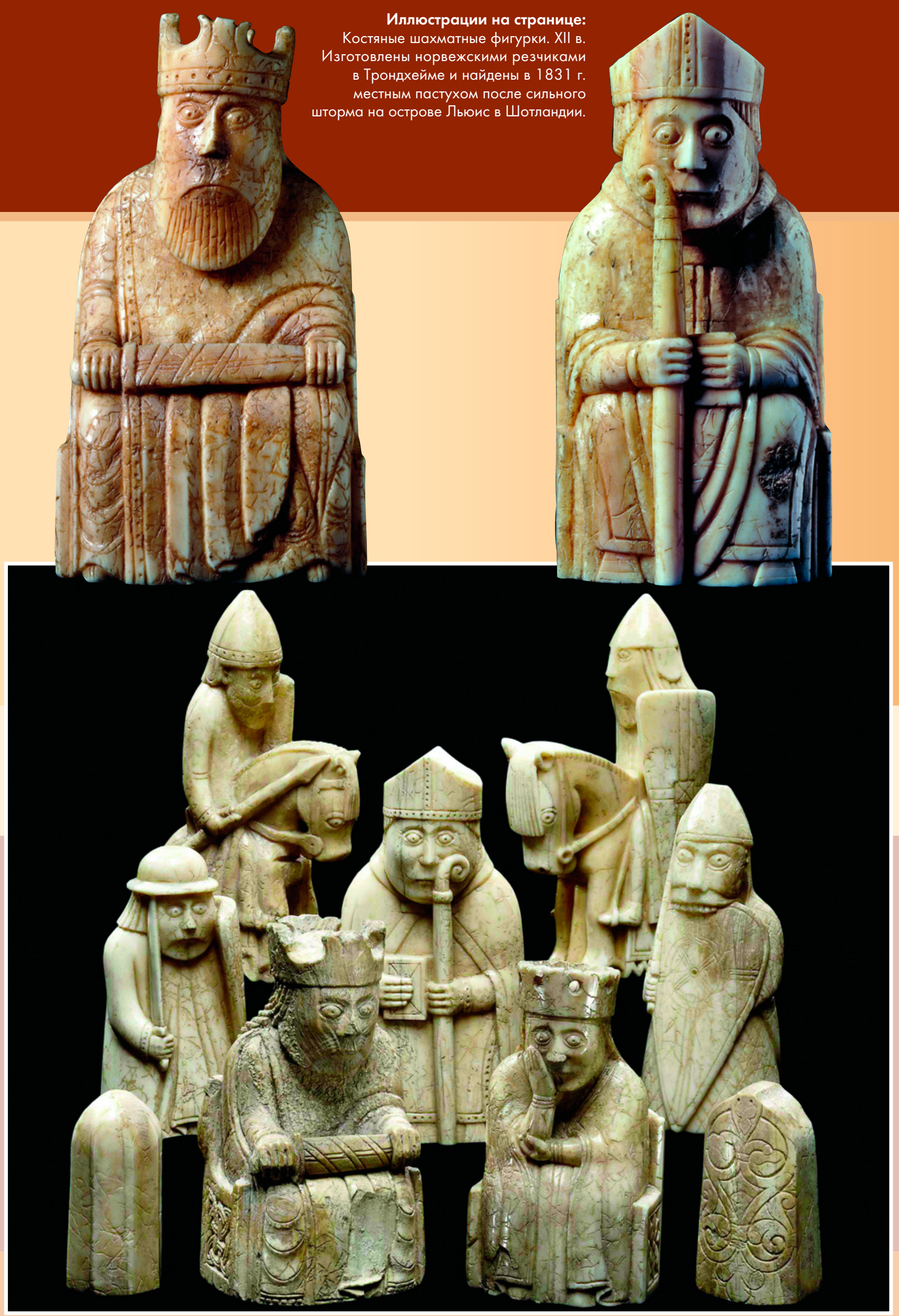

